\title{
New insight into global blue carbon estimation under human activity in land-sea interaction area: A case study of China
}

\author{
Yang Gao ${ }^{a}$, Guirui Yu ${ }^{\mathrm{a}, *}$, Tiantian Yang ${ }^{\mathrm{b}}$, Yanlong Jia ${ }^{\mathrm{a}}$, Nianpeng $\mathrm{He}^{\mathrm{a}}$, Jie Zhuang ${ }^{\mathrm{c}}$ \\ a Key Laboratory of Ecosystem Network Observation and Modeling, Institute of Geographic Sciences and Natural Resources Research, CAS, Beijing 100101, PRChina \\ b Department of Civil and Environmental Engineering, University of California, Irvine, CA 92697, United States \\ c Department of Biosystems Engineering and Soil Science, Institute for a Secure and Sustainable Environment, The University of Tennessee, Knoxville, TN 37996, United States
}

\section{A R T I C L E I N F O}

\section{Article history:}

Received 22 October 2015

Received in revised form 24 February 2016

Accepted 12 May 2016

Available online 14 May 2016

\section{Keywords:}

Coastal ecosystem

Blue carbon

Carbon sequestration

Human activity

Climate change

\begin{abstract}
A B S T R A C T
The $C$ sequestration in coastal blue carbon $\left(C_{b}\right)$ ecosystems, including mangroves, seagrasses and saltmarshes, was discovered to be useful in mitigating the increasing trend of carbon dioxide $\left(\mathrm{CO}_{2}\right)$ emission due to climate change. In this study, we systematically estimate traditional $C_{b}$ ecosystem distribution and the associated $C_{b}$ sequestration rate, and then further quantify the $C_{b}$ sinks fishery contribution to $C_{b}$ ecosystem due to human activity in coastal ecosystem. The results show that the global $C_{b}$ ecosystem is able to store $10.8 \mathrm{PgC}$, wherein biomass and soil are able to store 2.13 and $8.68 \mathrm{PgC}$, respectively. In China, the $C_{b}$ pools are $162 \mathrm{TgC}$ in mangroves, $67 \mathrm{TgC}$ in saltmarshes and $75 \mathrm{TgC}$ in seagrass. The human activity induced global $\mathrm{C}_{\mathrm{b}}$ sink fishery on $\mathrm{C}_{\mathrm{b}}$ ecosystem is about $26.58-37.6 \mathrm{TgC} \mathrm{yr}^{-1}$, accounting for $30.7 \%-43.4 \%$ of the world's traditional $\mathrm{C}_{\mathrm{b}}$ sequestration ecosystem. The global $C_{b}$ sequestration potential reaches up to $86.59 \mathrm{Tg} \mathrm{yr}^{-1}$, while China can explain $1.70 \%$ of the world's total $C_{b}$ sequestration. However, in China, the $C_{b}$ sequestration due to human activity reaches up to $6.32-7.89 \mathrm{TgC}^{-1}$, accounting for $20.9 \%-23.7 \%$ of global $C_{b}$ sink fishery. Therefore, it is very important to build the $C_{b}$ sink fisheries measure and monitor system to scientifically valuate $C_{b}$ sink fisheries and associated development potential.
\end{abstract}

(c) 2016 Elsevier B.V. All rights reserved.

\section{Contents}

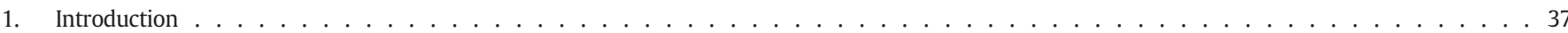

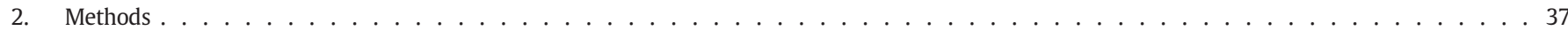

3. Global $C_{b}$ sink estimation in coastal ecosystem . . . . . . . . . . . . . . . . . . . . . . . . . . . . . . . . . . . . . . . . . . . . . . 37

3.1. Global $C_{b}$ ecosystem geographic distribution . . . . . . . . . . . . . . . . . . . . . . . . . . . . . . . . . . . . . . . 37

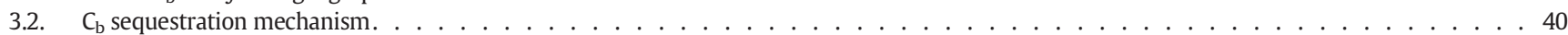

3.3. Global $C_{b}$ density in coastal ecosystem . . . . . . . . . . . . . . . . . . . . . . . . . . . . . . . . . . . . . . . . . 40

3.4. Global estimation of $C_{b}$ storage and sequestration potential . . . . . . . . . . . . . . . . . . . . . . . . . . . . . . . . . 41

4. $C_{b} \operatorname{sink}$ fishery . . . . . . . . . . . . . . . . . . . . . . . . . . . . . . . . . . . . . . . . . . . . . . . 41

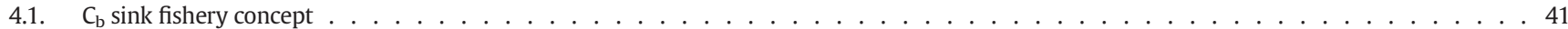

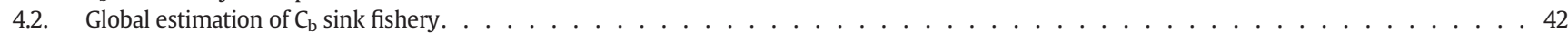

5. $C_{b}$ sink management and benefit . . . . . . . . . . . . . . . . . . . . . . . . . . . . . . . . . . . . 43

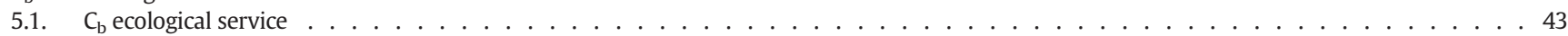

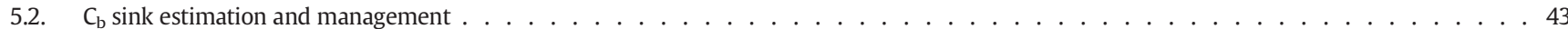

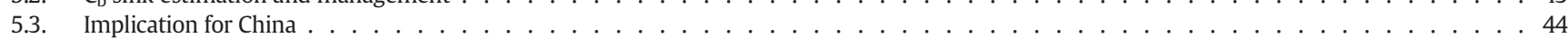

Acknowledgements . . . . . . . . . . . . . . . . . . . . . . . . . . . . . . . . . . . . . . . . . . 45

References. . . . . . . . . . . . . . . . . . . . . . . . . . . . . . . . . 45

\footnotetext{
* Corresponding author.

E-mail address: yugr@igsnrr.ac.cn (G. Yu).
} 


\section{Introduction}

Traditionally, the blue carbon $\left(C_{b}\right)$ is defined as the $C$ captured by living organisms in oceans that stored in the form of sediments from mangroves, saltmarshes and seagrasses (Siikamäki et al., 2012), The costal vegetated habitats, in particular mangroves, saltmarshes and seagrasses only cover less than $2 \%$ of the area of the world's oceans, but sequester at least $50 \%$ of the $C$ stored in ocean sediments (Nellemann et al., 2009; IWGCBC, 2011). Therefore, sustaining $C_{b}$ sinks in coastal ecosystems will be crucial for making climate change adaptation strategies and reducing vulnerability of human coastal communities in the future (Nellemann et al., 2009; Laffoley and Grimsditch, 2009). The land-sea interaction area in coastal ecosystem is commonly termed "gray zone" in the global $C$ cycle. The available findings and reports on $C_{b}$ ecosystem are important for evaluating global earth surface $\mathrm{C}$ storage (Sifleet et al., 2011).

$\mathrm{C}_{\mathrm{b}}$ biosequestration in mangroves, saltmarshes and seagrasses can capture atmospheric $\mathrm{CO}_{2}$ and store it in plant biomass and sediments as $C_{b}$. $C_{b}$ is considered as one of the most effective methods for longterm C storage (Duarte et al., 2013; Macreadie et al., 2014). $C_{b}$ sink is determined by the processes and mechanisms that marine organisms absorb and use atmospheric $\mathrm{CO}_{2}$ (Arrigo, 2004; Gonzalez et al., 2010). Marine organisms are responsible for $55 \%$ of global photosynthetic C fixation each year (Bowler et al., 2009; Bauer et al., 2013), but compared to terrestrial plants, phytoplanktonic marine organism biomass is only $0.05 \%$ of terrestrial plant biomass. The coastal ecosystem transports the fixed $\mathrm{C}_{\mathrm{b}}$ to two adjacent ecosystems, including coastal ecosystems and the open oceans, as well as to the seabed buried in sediments in the form of humus. (Duarte and Cebrian, 1996; Duarte et al., 2005; Bouillon et al., 2008; Heck et al., 2008; Bauer et al., 2013). Once $C_{b}$ is transformed into humus, it is temporarily removed from the $\mathrm{C}$ cycle. Donato et al. (2011) recently estimated that coastal mangroves could store up to $20 \mathrm{PgC}$, which was equivalent to roughly 2.5 times current annual greenhouse gas emissions globally. This is a striking observation, especially given the fact that mangroves only cover about $0.7 \%$ of the tropical forest area worldwide.

Recently, it has been reported that human activities have greatly modified the exchange of $C$ and nutrients between terrestrial and coastal zones (Regnier et al., 2013). Atwood et al. (2015) further revealed that predators were helpful for biosequestration and greatly changed the coastal ecosystem $\mathrm{C}$ cycling based on their indirect effects on plant or microbial community composition and structure (Wilmers et al., 2012; Atwood et al., 2014). Therefore, we believe that the human activities, such as $C_{b}$ fishery and aquaculture in coastal ecosystem, are able to alter food chain or increase the population of predators, and consequently enhance the $C_{b}$ biosequestration in coastal ecosystems. The aims of this study are to (1) summarize the current knowledge on $C_{b}$ ecosystem distribution and $C_{b}$ density; (2) comprehensively evaluate global $C_{b}$ sequestration potential and storage; (3) systematically estimate the contribution of $C_{b}$ sink fishery to coastal $C_{b}$ sequestration, and (4) provide recommendations for future $C_{b}$ management strategies.

\section{Methods}

In this study, in order to make sure the statistical data are uniform and unbiased, the basic statistical data on the distribution and $\mathrm{C}_{\mathrm{b}}$ sequestration of global mangroves, seagrasses and salt marshes were collected from the Food and Agriculture Organization (FAO) and International Working Group on Coastal "Blue Carbon" (IWGCBC) reports. The data on global fishery and aquaculture development were retrieved from the World Review of Fisheries and Aquaculture. The data related to $C_{b}$ ecosystem and fishery and aquaculture in China were extracted from China Marine Statistical Yearbook (CMSY) and China Fishery Statistical Yearbook (CFSY). All parameters used in the study are from published journal papers, conferences papers and government reports. The global $C_{b}$ storage and $C_{b}$ sequestration are estimated by the following equations and the detailed description of related parameter values is given in Table 1.

The coastal $C_{b}$ sequestrations are calculated using Eq. (1):

$\mathrm{C}_{\mathrm{b}}=C_{\text {rate }} \times A_{v}$

where $C_{\text {rate }}$ is the $C_{\mathrm{b}}$ sequestration rate of a certain kind of vegetation; $A_{v}$ is the distributing area for the corresponding $C_{b}$ ecosystem.

The economic algae, shellfish and fishing $C$ sequestration are calculated using Eq. (2):

$C_{\text {aquaculture }}=\mathrm{C}_{\mathrm{a}} \times X_{a}$

where $X$ is the annual mean production; $C_{a}$ is the $C$ sequestration rate.

\section{Global $C_{b}$ sink estimation in coastal ecosystem}

\subsection{Global $C_{b}$ ecosystem geographic distribution}

Mangroves, seagrasses and salt marshes in coastal ecosystem are three major $C_{b}$ pools, which spread across the globe. At least one of the three can be found in almost every country with a coastline (Giri et al., 2010; Pendleton et al., 2012; Siikamäki et al., 2012) (Fig. 1). Seagrass meadows often lie adjacent to mangroves and saltmarshes, which are subject to similar land-use pressures as mangroves though their much broader and different geographic range (Duarte and Chiscano, 1999; Hemminga and Duarte, 2000). Therefore, the estimation of areal coverage of saltmarshes and seagrass exist considerable uncertainty (Siikamäki et al., 2012). Barbier et al. (2011) estimated that the $C_{b}$ ecosystem on mangroves, seagrasses and saltmarshes covered approximately $4.9 \times 10^{5} \mathrm{~km}^{2}$ worldwide. Mangrove forests are coastal wetland forests that cover up to $75 \%$ of the tropical and subtropical shorelines of the world, so there are 111 countries with mangroves in the world (Siikamäki et al., 2012). Giri et al. (2010) reported that the total area of mangroves worldwide was $1.39 \times 10^{5} \mathrm{~km}^{2}$, wherein Southeast Asia had obvious the largest mangrove area $\left(66,687 \mathrm{~km}^{2}\right)$, which accounted for almost half of the total global mangroves area.

As Fig. 2 shows, we collect geographic data on the main mangroves and seagrass distribution in the top 20 countries in the world (Giri et al., 2011; Siikamäki et al., 2012). We find out that the main mangroves are concentrated on both sides of the equator and the total area for mangroves area in these 20 countries accounts for over $80 \%$ of the total area worldwide. The area of mangroves in Indonesia alone accounts for $2.7 \times 10^{4} \mathrm{~km}^{2}$ or $19.5 \%$ of the world's total mangroves area. Followed by Indonesia, the next four countries with large mangroves area are Brazil, Australia, Mexico and Nigeria, which belong to other continents (Fig.2a). As Fig.2b shows, seagrass ecosystems are broadly distributed worldwide. The total area of seagrass is roughly estimated at $3.19 \times 10^{5} \mathrm{~km}^{2}$. Meanwhile, there is an interesting phenomenon that mangroves mostly concentrate in developing countries around the equator, but seagrasses concentrate in both developing and developed countries (Giri et al., 2007). Southeast Asia has the largest area of seagrass. The total seagrass covered area in Southeast Asia is $8.13 \times 10^{4} \mathrm{~km}^{2}$, which accounts for $25.4 \%$ of the world's seagrass (Fig.2b). The top four seagrass covered countries are Australia, Saudi Arabia, United States and Indonesia. The total area of seagrass in Australia is $4.11 \times 10^{4} \mathrm{~km}^{2}$, which accounts for $12.9 \%$ of the world's total seagrass area. The salt marshes are mostly located in low temperate and high latitude area. In tropical areas, salt marshes would give way to mangroves (Allen and Pye, 1992). Chmura et al. (2003) roughly estimated that salt marshes covered $5.1 \times 10^{4} \mathrm{~km}^{2}$ worldwide, which was in agreement with the estimation from Pendleton et al. (2012).

In China, most of mangroves distribute at Guangdong, Guangxi, Hainan and Fujian Province, and the mangroves covered areas are 323, 180, 135 and $134 \mathrm{~km}^{2}$, respectively (CMSY, 2011). There are about 22 seagrass species distributed along China's coastal regions, which belong 
Table 1

Summary of parameter and values to calculate $C$ sequestration.

\begin{tabular}{|c|c|c|c|c|c|}
\hline $\begin{array}{l}\text { Parameters } \\
\text { (equation) }\end{array}$ & Type & $\begin{array}{l}\text { Value } \\
\text { (World) }\end{array}$ & References & $\begin{array}{l}\text { Value } \\
\text { (China) }\end{array}$ & References \\
\hline \multirow[t]{4}{*}{$\begin{array}{l}C_{\text {rate }} \\
((1))\end{array}$} & Mangroves & $\begin{array}{l}226 \\
(20-949) \\
\mathrm{gC} \mathrm{m}^{-2} \\
\mathrm{y}^{-1}\end{array}$ & Chmura et al. (2003), Duarte et al. (2005), Giri et al. (2011), Spalding et al. (2010) & $\begin{array}{l}444.27 \mathrm{gC} \\
\mathrm{m}^{-2} \mathrm{y}^{-1}\end{array}$ & $\begin{array}{l}\text { Duarte et al. (2005), Duan et al. } \\
\text { (2008) }\end{array}$ \\
\hline & Seagrasses & $\begin{array}{l}138 \\
(45-190) \\
\mathrm{gC} \mathrm{m}^{-2} \\
\mathrm{y}^{-1}\end{array}$ & $\begin{array}{l}\text { Charpy-Roubaud and Sournia (1990), Green and Short (2003), Duarte et al. } \\
\text { (2005), Duarte et al. (2010), Kennedy et al. (2010) }\end{array}$ & $\begin{array}{l}83 \mathrm{gC} \mathrm{m}{ }^{-2} \\
\mathrm{y}^{-1}\end{array}$ & $\begin{array}{l}\text { Duarte and Chiscano (1999), Duarte } \\
\text { (2002), Zhang et al. (2015) }\end{array}$ \\
\hline & Saltmarshes & $\begin{array}{l}218 \\
(18-1717) \\
\mathrm{gC} \mathrm{m}^{-2} \\
\mathrm{y}^{-1}\end{array}$ & Chmura et al. (2003), Duarte et al. (2005) & $\begin{array}{l}235.62 \mathrm{gC} \\
\mathrm{m}^{-2} \mathrm{y}^{-1}\end{array}$ & $\begin{array}{l}\text { Duarte et al. (2005)., Duan et al. } \\
\text { (2008) }\end{array}$ \\
\hline & Corals reefs & $\begin{array}{l}148 \mathrm{gC} \\
\mathrm{m}^{-2} \mathrm{y}^{-1}\end{array}$ & Duarte et al. (2005) & $\begin{array}{l}148 \mathrm{gC} \mathrm{m}^{-2} \\
\mathrm{y}^{-1}\end{array}$ & Duarte et al. (2005) \\
\hline \multirow[t]{4}{*}{$\begin{array}{l}A_{v} \\
((1))\end{array}$} & Mangroves & $\begin{array}{l}139,170 \\
\mathrm{~km}^{2}\end{array}$ & Giri et al. (2011), FAO (2007) & $827.57 \mathrm{~km}^{2}$ & CMSY (2011) \\
\hline & Seagrasses & $\begin{array}{l}319,000 \\
\mathrm{~km}^{2}\end{array}$ & Siikamäki et al. (2012) & $8276 \mathrm{~km}^{2}$ & Siikamäki et al. (2012) \\
\hline & $\begin{array}{l}\text { Salt } \\
\text { marshes }\end{array}$ & $51,000 \mathrm{~km}^{2}$ & Siikamäki et al. (2012), Pendleton et al. (2012) & $1717 \mathrm{~km}^{2}$ & CMSY (2011), Duan et al. (2008) \\
\hline & Corals reefs & $112000 \mathrm{~km}^{2}$ & Chen et al. (2003) & $222.17 \mathrm{~km}^{2}$ & Lan and Chen (2006) \\
\hline \multirow[t]{4}{*}{$\begin{array}{l}X_{a} \\
((2))\end{array}$} & Algae & $1.71 \times 10^{7} \mathrm{t}$ & Yan et al. (2011a, 2011b) CFSY (2012) & $1.41 \times 10^{7} \mathrm{t}$ & $\begin{array}{l}\text { Yan et al. (2011a, 2011b), CFSY } \\
\text { (2012) }\end{array}$ \\
\hline & Shellfish & $1.26 \times 10^{7} \mathrm{t}$ & CMSY (2011) & $1.05 \times 10^{7} \mathrm{t}$ & CMSY $(2011)$ \\
\hline & $\begin{array}{l}\text { Fish } \\
\text { catching }\end{array}$ & $7.9 \times 10^{7} \mathrm{t}$ & FAO (2014) & $1.24 \times 10^{7} \mathrm{t}$ & FAO (2014) \\
\hline & $\begin{array}{l}\text { Fish } \\
\text { aquaculture }\end{array}$ & $5.55 \times 10^{6} \mathrm{t}$ & FAO (2014) & $1.02 \times 10^{6} \mathrm{t}$ & FAO (2014) \\
\hline \multirow[t]{4}{*}{$\begin{array}{l}C_{a} \\
((2))\end{array}$} & Algae & $\begin{array}{l}274-312 \\
\mathrm{gC} \mathrm{kg}^{-1}\end{array}$ & Yan et al. (2011a, 2011b), Zhang et al. (2005) & $\begin{array}{l}274-312 \mathrm{gC} \\
\mathrm{kg}^{-1}\end{array}$ & $\begin{array}{l}\text { Yan et al. (2011a, 2011b), Zhang et } \\
\text { al. (2005) }\end{array}$ \\
\hline & Shellfish & $\begin{array}{l}62.9 \mathrm{gC} \\
\mathrm{kg}^{-1}\end{array}$ & Duarte et al. (2005) & $\begin{array}{l}22.7-88.7 \\
\mathrm{gC} \mathrm{kg}^{-1}\end{array}$ & Zhang (2013) \\
\hline & $\begin{array}{l}\text { Fish } \\
\text { catching }\end{array}$ & $3-15 \%$ & Wilson et al. (2009), Lavery et al. (2010) & $11.5-12.7 \%$ & Yang et al. (2012) \\
\hline & $\begin{array}{l}\text { Fish } \\
\text { aquaculture }\end{array}$ & $3-15 \%$ & Wilson et al. (2009), Lavery et al. (2010) & $11.5-12.7 \%$ & Yang et al. (2012) \\
\hline
\end{tabular}

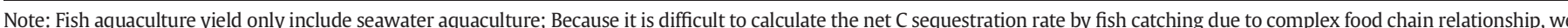

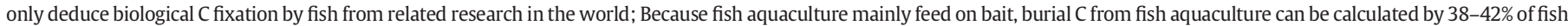
yield reported by Song (2011), and the final $C_{b}$ sink from fish aquaculture is calculated by biological C plus burial $C$.

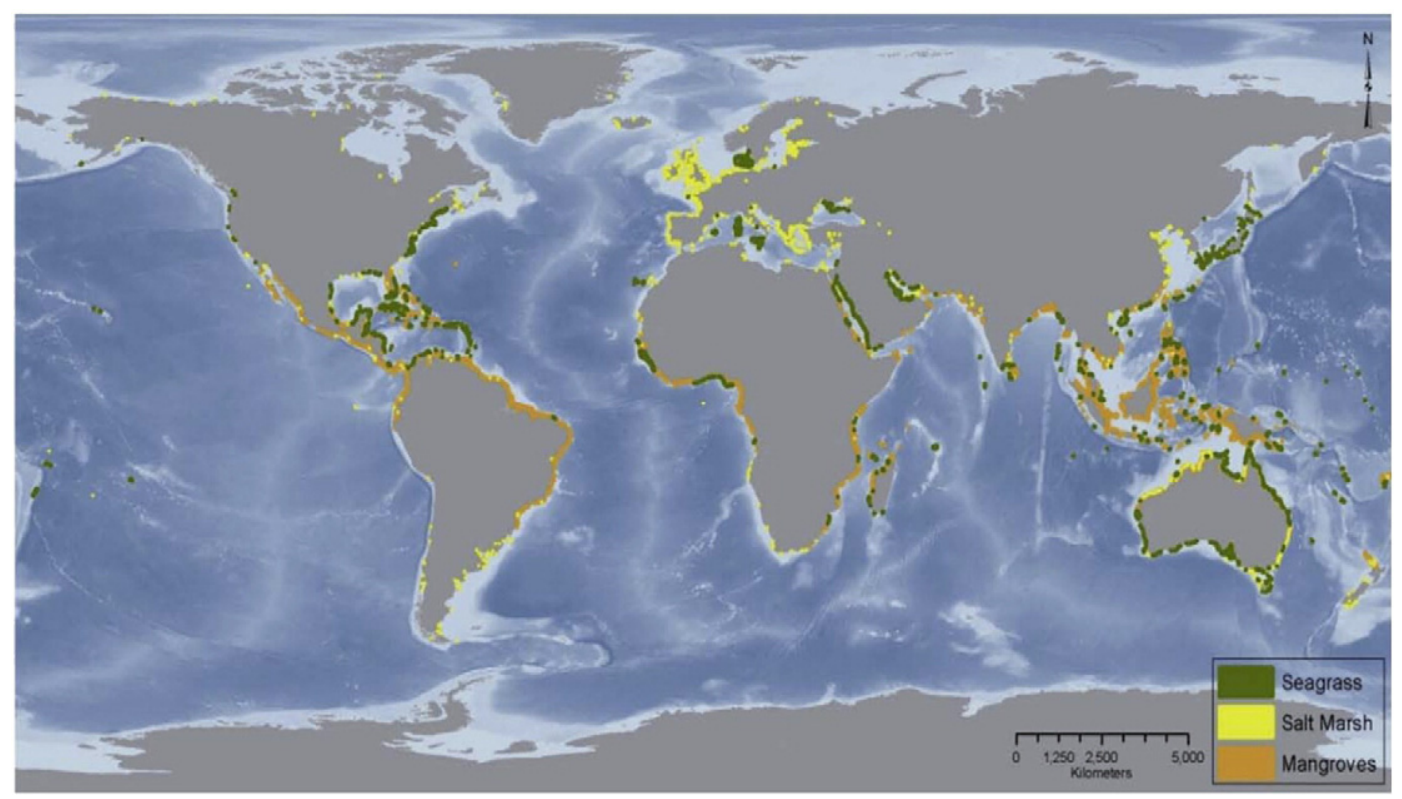

Fig. 1. Global distribution of seagrasses, saltmarshes and mangroves (Pendleton et al., 2012). 

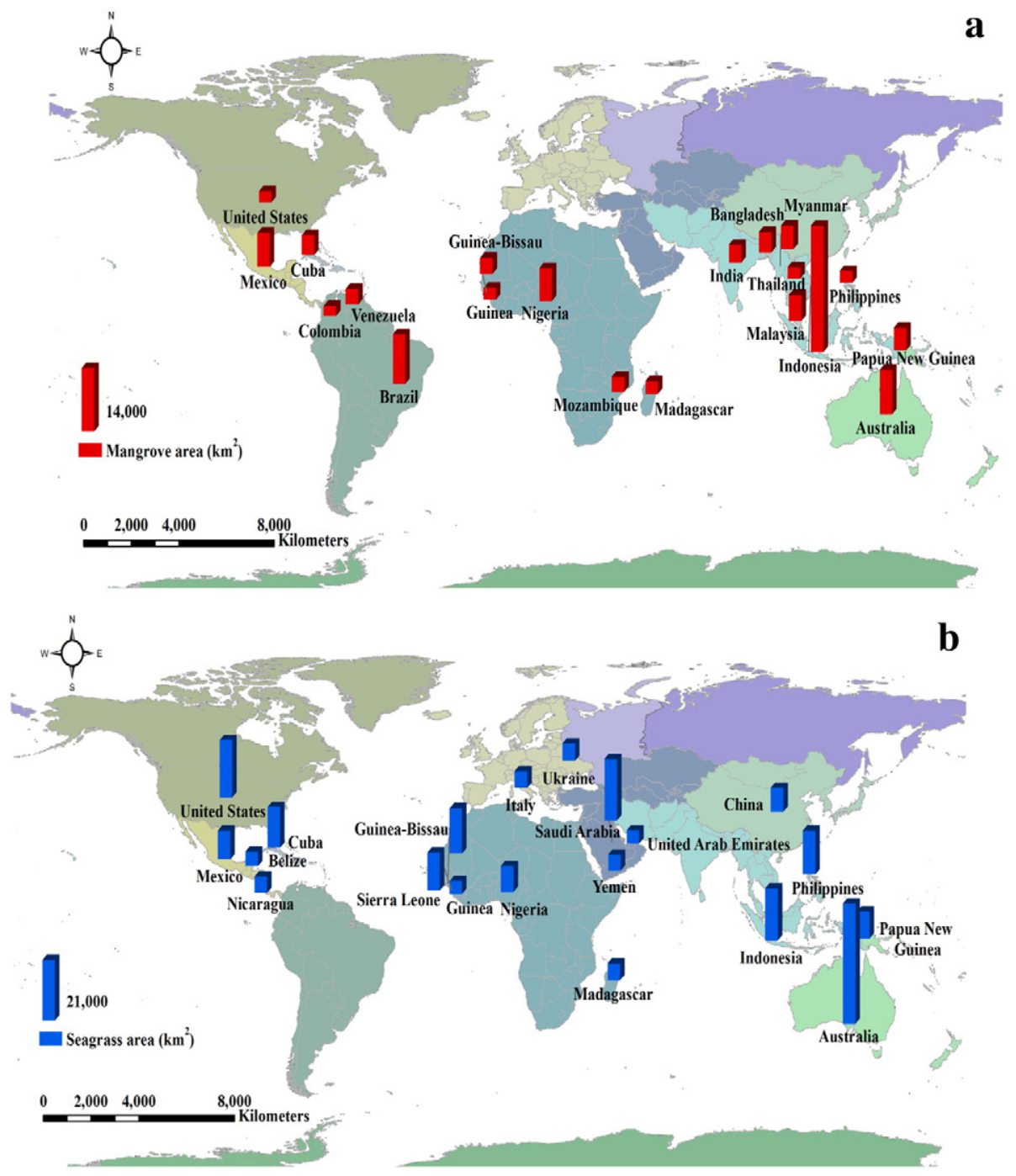

Fig. 2. Mangroves distribution (a) and seagrass distribution (b) in main top 20 countries.

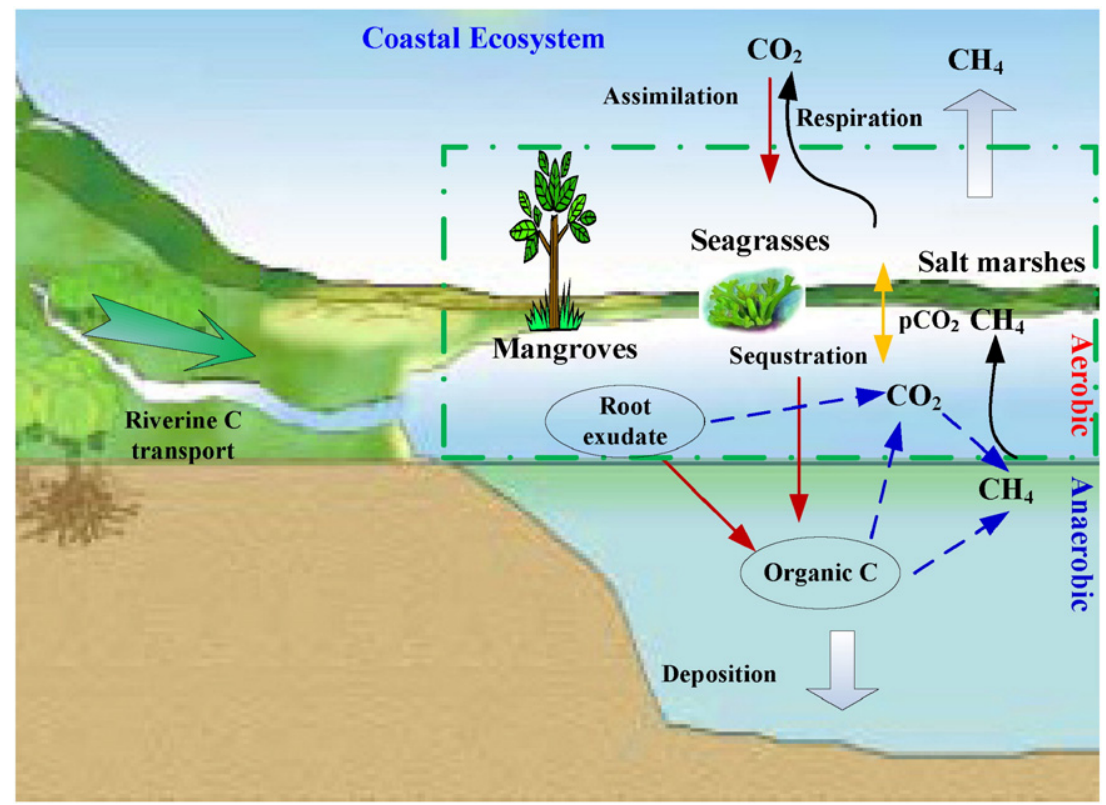

Fig. 3. $C_{b}$ sequestration Process by mangroves, seagrasses and saltmarshes in coastal ecosystem. 
to ten genera or four families, accounting for about $30 \%$ of known seagrass species worldwide (Zheng et al., 2013). The total distribution area of seagrass meadows in China was estimated at $8267 \mathrm{~km}^{2}$ (Siikamäki et al., 2012), wherein Hainan, Guangdong and Guangxi province accounting for $64 \%, 11 \%$ and $10 \%$ of the total of area, respectively. Saltmarsh wetlands in China had an unbalanced geographical distribution.The regions that contain large amount of saltmarsh in China are the Bohai Sea, the Yellow Sea and the East China Sea. Most of the saltmarsh wetlands in China have been shrinking or exhibiting a decreasing trend. The total of area of saltmarsh wetland in China was estimated at $1717 \mathrm{~km}^{2}$ by Duan et al. (2008).

\section{2. $C_{b}$ sequestration mechanism}

As Fig. 3 shows, coastal ecosystem $C_{b}$ is primarily sequestrated by organic matter via photosynthetic immobilization of atmospheric $\mathrm{CO}_{2}$. Excess $\mathrm{CO}_{2}$ would respire back into the atmosphere (Gattuso et al., 1998; Duarte et al., 2005). Mangrove roots have the capacity to simultaneously prevent saltwater intake and transport oxygen into harsh intertidal soils. Thus, their stilt and other aerial roots above the soil surface can directly uptake gases such as atmospheric $\mathrm{CO}_{2}$ (Spalding et al., 2010). Aerial roots of mangroves can also trap suspended nutrients, peat, and $C$ sediments from terrestrial ecosystems. This is the result of inland erosion and riverine transport (Spalding et al., 2010; Miao et al., 2011; Siikamäki et al., 2012; Miao et al., 2015; Kong et al., 2015). C bould therefore be buried in saltmarshes within living aboveground and belowground biomass over annual to decadal timescales (Theuerkauf et al., 2015). Sources of biogenic $C$ in salt marshes include grasses, benthic algae, and bacteria (Leonard and Luther, 1995). The riverine transport of C (as well as phytoplankton and microphytobenthos) to estuaries are potential allogenic sources of $C_{b}$ into saltmarshes (Ghebrehiwet et al., 2009; Yang et al., 2015). In addition, saltmarshes can trap allogenic C from the water column (Theuerkauf et al., 2015).

Seagrass is the most productive ecosystem on Earth (Duarte and Chiscano, 1999). Its total primary production is almost equal to angiosperms and the epiphytes and macroalgae that they support (Hemminga and Duarte, 2000). Accordingly, the abundance and activity of heterotrophs in seagrass meadows would also be greatly enhanced (Hemminga and Duarte, 2000) with higher community respiration rates (Middelburg et al., 2005). Furthermore, a significant fraction of seagrass production occurs in sediments, such as roots and rhizome material (Mateo et al., 1997; Duarte et al., 2010). It should be noted that all the above $C_{b}$ sink processes are strongly autotrophic in nature (Gattuso et al., 1998; Duarte et al., 2005). Some $C_{b}$ sequestrated by mangroves, salt marshes, and seagrass would be buried in sediments, which can be stored over millenary timescales (Mateo et al., 1997). Based on estimations by Duarte et al. (2005), global vegetated coastal habitats accumulate approximately from 120 to $329 \mathrm{TgC}_{\mathrm{gr}}{ }^{-1}$ on the seafloor, thus acting as efficient $C_{b}$ sinks, which accounts for at least half of the lower estimate for global $C$ burial in marine sediments (Nellemann et al., 2009). Excess $C_{b}$ would be exported into adjacent open oceans and terrestrial ecosystems (Bouillon et al., 2008).

\subsection{Global $C_{b}$ density in coastal ecosystem}

The $C_{b}$ ecosystem is different from many other ecosystems, because the majority of $C_{b}$ in coastal ecosystem are immobilized and trapped in soil (Donato et al., 2011). Therefore, the estimation of $C_{b}$ density in soil is an important step to understand the $C_{b}$ sequestration potential in coastal ecosystem. Globally, annual coastal vegetation is around 120

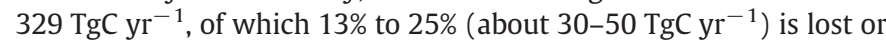
buried under oceans (Duarte et al., 2005). Bouillon et al. (2008) indicated that mangroves contained substantial amounts of $C_{b}$ and the $C_{b}$ density in mangrove ecosystems exhibited spatial variation. Soil $C$ accounts for the majority of $C_{b}$ stored in mangrove ecosystems (Donato et al., 2011). Therefore, understanding the potential $C_{b}$ density at the global level will be important to evaluate the economic potential of different locations for $C_{b}$ conservation (Suratman, 2008). Due to the availability of the $C_{b}$ sink geographical data for seagrass and saltmarsh, in this study we only focus on $C_{b}$ density and associated geographical distribution for mangrove soil.

As Fig. 4 shows, we find out that the $C$ density in mangrove soils is the highest in South Asia with an average density of 0.021$0.042 \mathrm{gC} \mathrm{cm}^{-3}$, and the $\mathrm{C}$ density in mangrove soils is $0.025 \mathrm{gC} \mathrm{cm}^{-3}$ in East Asia. The $\mathrm{C}$ density in mangrove soils in the Middle East is only $0.022 \mathrm{gC} \mathrm{cm}^{-3}$, which is the lowest as compared to other region in the world. In addition, the $\mathrm{C}$ densities in mangrove soils in Africa and America are $0.023-0.036 \mathrm{gC} \mathrm{cm}^{-3}$ and $0.031-0.041 \mathrm{gC} \mathrm{cm}^{-3}$, respectively. In both Africa and America, there are significant spatial variations of the total amount of $\mathrm{C}$ in mangrove soil. However, the availability of spatial data on saltmarsh and seagrass at global scale are not sufficient to make a global assessment. Chmura et al. (2003) estimated that the

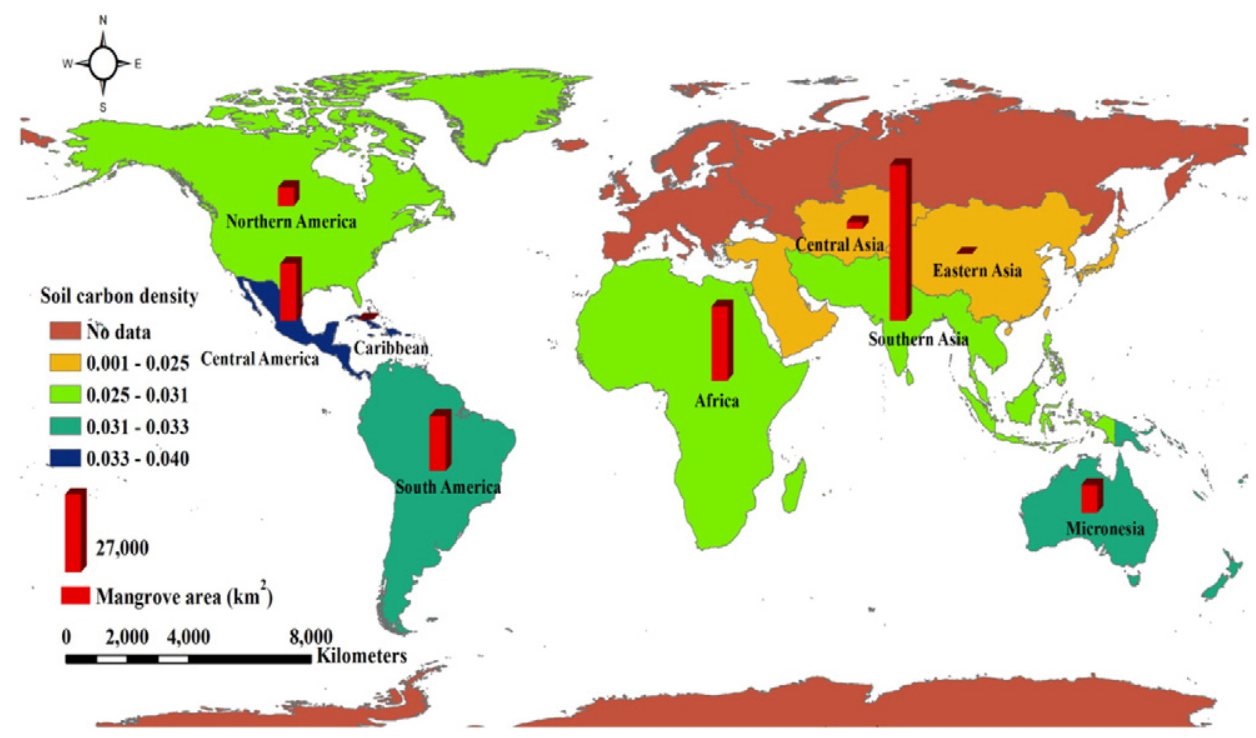

Fig. 4. Global estimation of carbon density in mangroves and mangroves area in different continent. 
average $C$ density in salt marsh was $0.039 \mathrm{gC} \mathrm{cm}^{-3}$, which was close to that in mangroves. For $\mathrm{C}$ density in seagrass, Laffoley and Grimsditch (2009) reported that the soil C volume was $70 \mathrm{tC} \mathrm{ha}{ }^{-1}$. Duarte et al. (2005) estimated that the average $C$ burial for seagrasses was $83 \mathrm{gC} \mathrm{m}^{-2} \mathrm{yr}^{-1}$ and Kennedy et al. (2010) found out that there was approximately $41.5 \mathrm{gC} \mathrm{m}^{-2} \mathrm{yr}^{-1}$ of seagrass biomass being stored in seagrass sediments.

\subsection{Global estimation of $C_{b}$ storage and sequestration potential}

Globally, the $\mathrm{C}$ sequestration potential for mangroves is

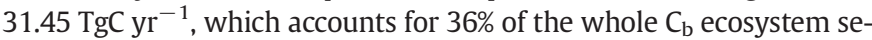
questration. In addition, seagrass beds are the primary producers (Duarte and Chiscano, 1999), with the greatest productivity sequestration potential (44.02 $\mathrm{TgC}^{-1}$ ) as compared to saltmarsh and mangroves (Duarte, 2002). In microbial community, the extent of organic matter accumulation is determined by the total utilization amount of $C_{b}$ that sequestered within seagrass sediments. Detrital material is the most important seagrass-derived $C_{b}$ source for the microbial community in seagrass sediment, and its subsequent breakdown by microorganisms is a vital component of C cycling (Guy, 2010).

The $C$ sequestration by $C_{b}$ ecosystem in China is different from that in the globe. The global $C_{b}$ sequestration potential reaches up to 86.59 $\mathrm{Tg} \mathrm{yr}^{-1}$, while China can explain $1.70 \%$ of the world's $C_{b}$ sequestration. The $C_{b}$ sequestration potential in China is estimated at $0.41 \mathrm{TgC} \mathrm{yr}^{-1}$ in saltmarshes and $0.37 \mathrm{TgC} \mathrm{yr}^{-1}$ in mangroves. Seagrasses are able to fix significant amounts of atmospheric $\mathrm{CO}_{2}$ (Kaiser et al., 2005). The total seagrass covered area is about $8267 \mathrm{~km}^{2}$ in China, which accounts for $2.6 \%$ of the world's seagrass area (Siikamäki et al., 2012). Therefore, the current study infers that the $C_{b}$ sequestration potential of seagrass in China is $0.69 \mathrm{TgC}^{-1}{ }^{-1}$. The $C_{b}$
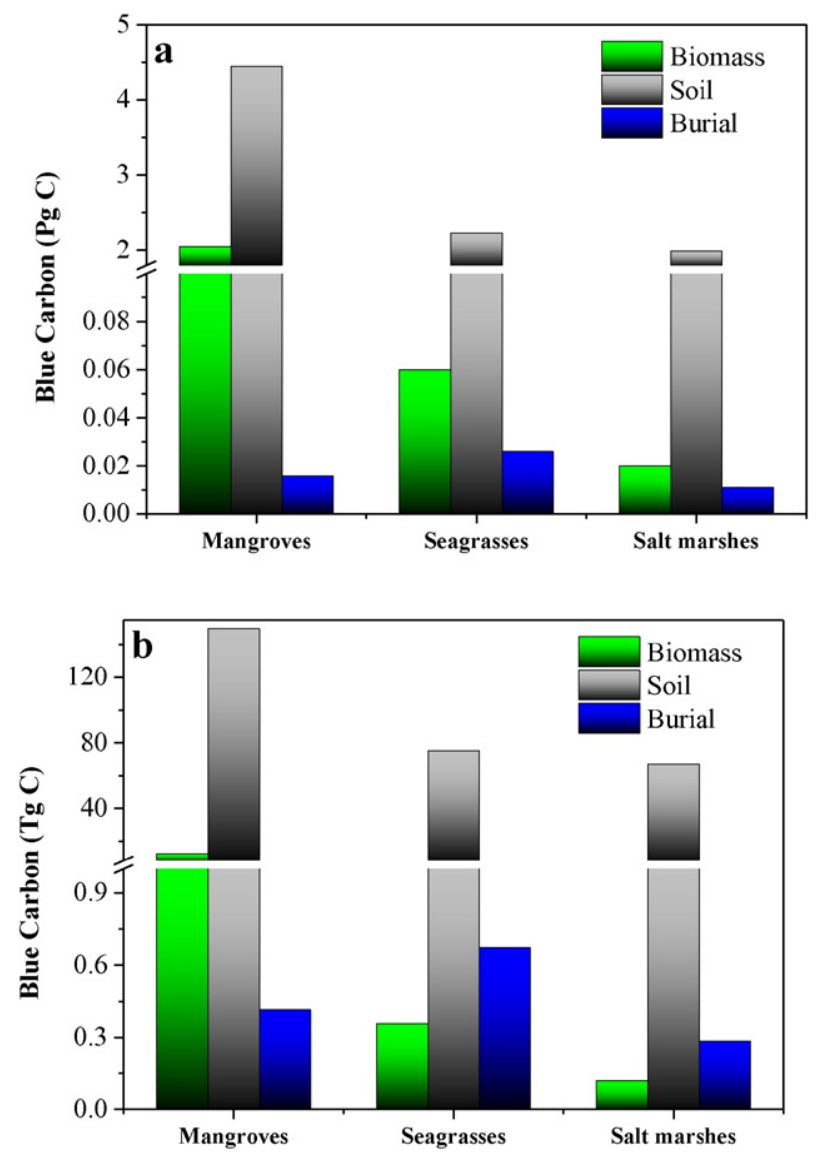

Fig. 5. Estimation of $C_{b}$ stock and burial for mangroves, seagrass and saltmarshes in the world (a) and China (b). acts as a sink and the capacity is largely dependent on the amount of organic matter accumulated within sediments following microbial transformation (Guy, 2010). In China, seagrass is the primary source for C sequestration. The total $C$ sequestration in China equals to $47 \%$ of the whole $C_{b}$ ecosystem sequestration, while the $C$ sequestration from mangroves in China only accounts for $25 \%$ of that in the world.

Based on the $C_{b}$ density at $1 \mathrm{~m}$ depth (Fig. 5), we further estimate the global $C_{b}$ stored by the three $C_{b}$ ecosystems. Mangroves are the primary source of $C_{b}$ storage at global scale. The total stored and buried $C_{b}$ in mangroves are $6.5 \mathrm{PgC}$ (soil plus biomass) and $16 \mathrm{TgC}$, respectively, wherein the average burial rate is around $1.15 \mathrm{tC} \mathrm{ha}^{-1}$ (Fig.5a) (Twilley et al., 1992; Chmura et al., 2003; Kristensen et al., 2008; Donato et al., 2011) The total biomass $C_{b}$ storage in saltmarshes is very small $(17 \mathrm{TgC})$, and the stock density is only $1.15 \mathrm{tC} \mathrm{ha}^{-1}$. The $\mathrm{C}_{\mathrm{b}}$ storage density in soil for saltmarshes is $390 \mathrm{tC} \mathrm{ha}^{-1}$ and has $2 \mathrm{PgC}$ of total C stock (Mitsch and Gosselink, 1993; Cebrian, 1999; Chmura et al., 2003).The $C_{b}$ storage density in seagrass is approximately $72 \mathrm{tC} \mathrm{ha}^{-1}$ and the total $\mathrm{C}$ stock is $2.3 \mathrm{PgC}$, wherein the $\mathrm{C}_{\mathrm{b}}$ storage in biomass and soil are 0.559 and $2.233 \mathrm{PgC}$, respectively (Duarte and Chiscano, 1999; Duarte et al., 2005; Laffoley and Grimsditch, 2009; Kennedy et al., 2010). In addition, burial $C_{b}$ rate and total $C$ stock in seagrass can reach $0.83 \mathrm{tC} \mathrm{ha}^{-1}$ and $26 \mathrm{TgC}$, respectively (Kennedy et al., 2010; Duarte et al., 2010). Therefore, the global $C_{b}$ ecosystem is estimated to have a C capacity of $10.8 \mathrm{PgC}$, wherein the capacities of biomass and soil are 2.13 and $8.68 \mathrm{PgC}$, respectively. The global burial $C_{b}$ in coastal ecosystem is able to reach up to $53 \mathrm{TgC}$. Based on the above statistics on the $C_{b}$ ecosystem area in China, we estimate that the total amounts of $C_{b}$ (biomass plus soil) pools in China are $162 \mathrm{TgC}, 67 \mathrm{TgC}$ and $75 \mathrm{TgC}$ in mangroves, saltmarshes and seagrass, respectively. The estimated burials $C_{b}$ in mangroves, saltmarshes and seagrass ecosystem are $0.41,0.67$ and $0.29 \mathrm{TgC}$, respectively (Fig. $5 \mathrm{~b}$ ).

\section{4. $C_{b}$ sink fishery}

\section{1. $C_{b}$ sink fishery concept}

$C_{b}$ ecosystem also provides a diverse array of ecosystem services such as fishery production and catching, coastline protection, pollution buffering, and high rates of $C$ sequestration (Barbier et al., 2011). Therefore, except traditional three main $C_{b}$ sink, we consider the human activities, such as algae and shellfish aquaculture, fish aquaculture and fish catching in coastal ecosystem, to be the another form of $C_{b}$ sink with great potential that affects $C_{b}$ ecosystem. As Fig. 6 shows, shellfish can fix inorganic $\mathrm{C}$ in seawater by calcification, such as $\mathrm{HCO}_{3}^{-}$, and then release $\mathrm{CO}_{2}$ to seawater and atmosphere. The amount of $\mathrm{CO}_{2}$ directly being released to atmosphere is about $0.67 \mathrm{~mol}$ (Frankignoulle and Canon, 1994), and shellfish is able to absorb $2 \mathrm{~mol}$ of $\mathrm{CO}_{2}$. Meanwhile, the respiration from shellfish will also release $\mathrm{HCO}_{3}^{-}$to seawater. Both calcification and respiration alter inorganic $\mathrm{C}$ cycle in oceanic ecosystem. The $C_{b}$ sink during shellfish aquaculture mainly happens during the process of predating and excreting from shellfish and catching shellfish from seawater. During predating and excreting, shellfish is feed on algae and then excrete $C$. The excreted $C$ will be buried and sealed in the seafloor. The shellfish catching is considered as an $C_{b}$ transfer process. The $C_{b}$ sink process caused by algae aquaculture is similar with seagrass. Abundant $C_{b}$ is produced through the photosynthesis by algae aquaculture, wherein part of the produced $C_{b}$ is stored in the sediments and other part is removed by harvest. The $\mathrm{CO}_{2}$ released by algae's respiration will mix with seawater and be transported back to atmosphere.

The complete $C_{b}$ sink process by fish aquaculture and fishery mainly includes $C$ transfer by catching and fish excrete processes (Fig. 6). Fish consumes microalgae, macroalgae and seagrass or predate living organism, and then excretes $C$ to seafloor. The amount of excreted $C$ from fish is significantly larger than that from shellfish. Coral's white calcareous skeleton also exhibits $s C_{b}$ sink function by calcification and has high productivity in coastal ecosystem (Chen et al., 2003). Therefore, the 


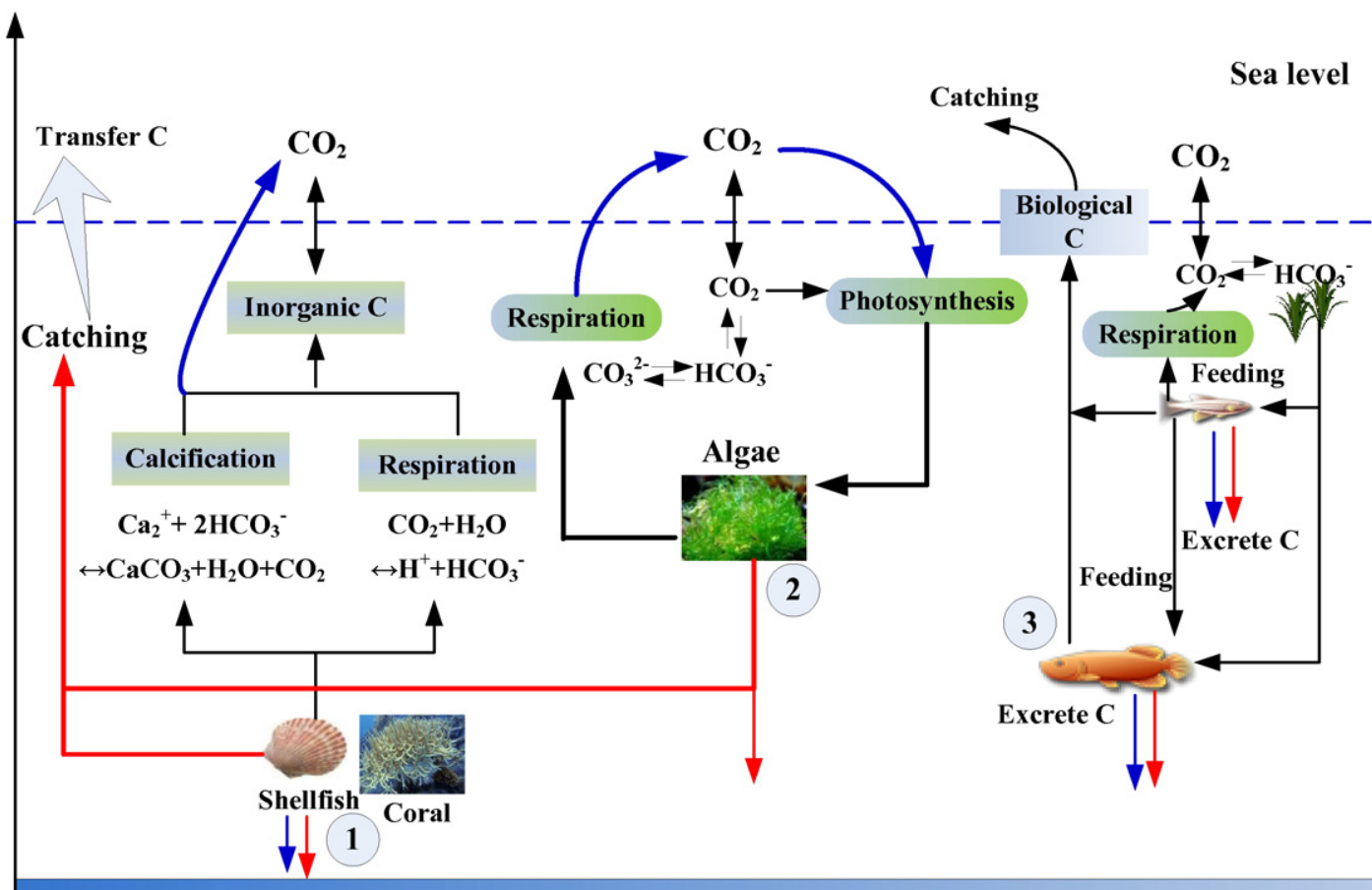

Sea floor

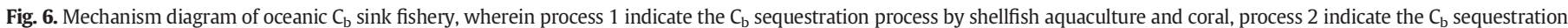

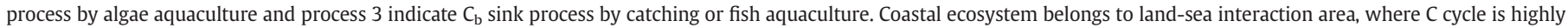

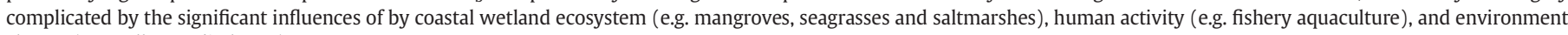
change (e.g. pollutant discharge).

coral reefs' $C_{b}$ sink mechanism is considered as same as that with shellfish aquaculture in this study.

\subsection{Global estimation of $C_{b} \operatorname{sink}$ fishery}

Duarte et al. (2009) reported that the growth rate on mariculture has been almost doubled in 10 years, and mariculture production has increased 10 -fold in 30 years. Therefore, it is inferable that human activity has a considerable impact on global $C_{b}$ ecosystem. The influence from human activity primarily takes place on $C_{b}$ pool and $C_{b}$ sequestration in coastal ecosystem. The human activity induced $\mathrm{C}_{\mathrm{b}} \operatorname{sink}$ fishery on $\mathrm{C}_{\mathrm{b}}$ ecosystem is about $26.58-37.6 \mathrm{TgC}_{\mathrm{yr}}{ }^{-1}$, accounting for $30.7 \%-43.4 \%$ of the world's traditional $\mathrm{C}_{\mathrm{b}}$ sequestration ecosystem. Assuming that all $\mathrm{CO}_{2}$ absorbed by economic algae comes from the atmosphere, the calculated annual $C_{b}$ sequestration by economic algae worldwide is 4.65-5.30 $\mathrm{TgC}^{-1} \mathrm{r}^{-1}$ (Fig. 7). The world annual average shellfish aquaculture production is $1.26 \times 10^{7} \mathrm{t}$, which might lead to a long-term confine-

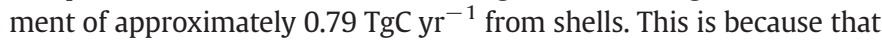
shell matter in the upper levels of oceans is another important factor that determines the $\mathrm{CO}_{2}$ absorb rate of seawater (Duarte et al., 2005). Shells could help enhance $\mathrm{CO}_{2}$ uptake by dissolution in seawater, but the rate at which they dissolve is controlled by seawater acidity levels. Moreover, the process, from acidity contacts and dissolves vulnerable calcite deposits to carbonate cations arises to combine with $\mathrm{CO}_{2}$ in surface seawater, takes extremely long time (Baliño et al., 2001).

Song (2011) reported that $1 \mathrm{t}$ of fishery stocks and supplies would produce $878-952 \mathrm{~kg}$ of $\mathrm{C}$ entering seawater, accounting for $75 \%$ to $78 \%$ of the amount of total C input. According to Song (2011), 40\% of the total $\mathrm{C}$ input would be in the dissolved form and $44 \%$ in the particulate form, which included bait residue, and excrement. According to FAO (2014), the global $C_{b}$ sinks by fishery aquaculture and fish catching were 2.27-3.16 $\mathrm{TgC}^{-1} r^{-1}$ and 2.37-3.16 $\mathrm{TgC}^{-1}{ }^{-1}$, respectively (Fig.
7). As a result of continues environmental pollution and climate warming, coral reefs have decreased in area from 6 to $1.12 \times 10^{5} \mathrm{~km}^{2}$, and this trend is gradually increasing (Gattuso et al., 1998; Duarte et al., 2005). Even though coral reefs cover only $1.12 \times 10^{5} \mathrm{~km}^{2}$ of surface area in the world, they are very productive (Chen et al., 2003). According to Duarte et al. (2005), coral reefs' C sequestration rate was about $148 \mathrm{gC} \mathrm{m}^{-2} \mathrm{yr}^{-1}$. Therefore, the global $\mathrm{C}_{\mathrm{b}}$ sequestration potential of coral reefs will reach up to $16.5{\mathrm{TgC} \mathrm{yr}^{-1}}^{-1}$. Due to mounting human environmental disturbances, coastal coral reef zones will become stronger atmospheric $\mathrm{CO}_{2}$ sinks in the future.

The $C_{b}$ sinks by shellfish and algae aquaculture in China are close to that worldwide. The total $C_{b}$ in shellfish and algae aquaculture in China accounts for $70-80 \%$ of the world's total sequestration. China has an annual average algae production of $1.41 \times 10^{7} \mathrm{t}$ (CFSY, 2012; FAO, 2014), so the calculated annual $C_{b}$ sequestration by economic algae in China is estimated to be $3.84-4.36 \mathrm{TgC}^{-1}$ (Fig. 8). Given the fact that average annual shellfish aquaculture production in China is $1.05 \times 10^{7} \mathrm{t}$

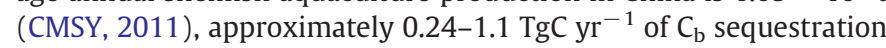
will be confined within shells. The shells confined $C_{b}$ accounts for $83.9 \%$ of global $C$ sequestration by shellish aquaculture.

The $\mathrm{C}$ transported by fish catching and fishing production in China accounts for $15-18 \%$ of the total amount in the world. Therefore, we estimate that the annual amount of $C$ removed by fish catching will reach

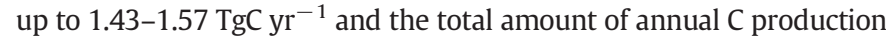
by the fishery industry in China is around $0.51-0.56 \mathrm{TgC}^{-1}{ }^{-1}$. Currently, the coral reef area in China is only $222.17 \mathrm{~km}^{2}$, which only accounts for $0.2 \%$ of total global coral reef $C$. The coral reef's area in China is mainly located in the South China Sea. In this region, approximately $55 \%$ of these coral reefs have disappeared since the 1960s (Lan and Chen, 2006). Considering the large reduction of coral reef area in China, we estimate that the $C_{b}$ sequestration potential for corals reefs in China to be $0.3 \mathrm{TgC}_{\mathrm{yr}}{ }^{-1}$. 


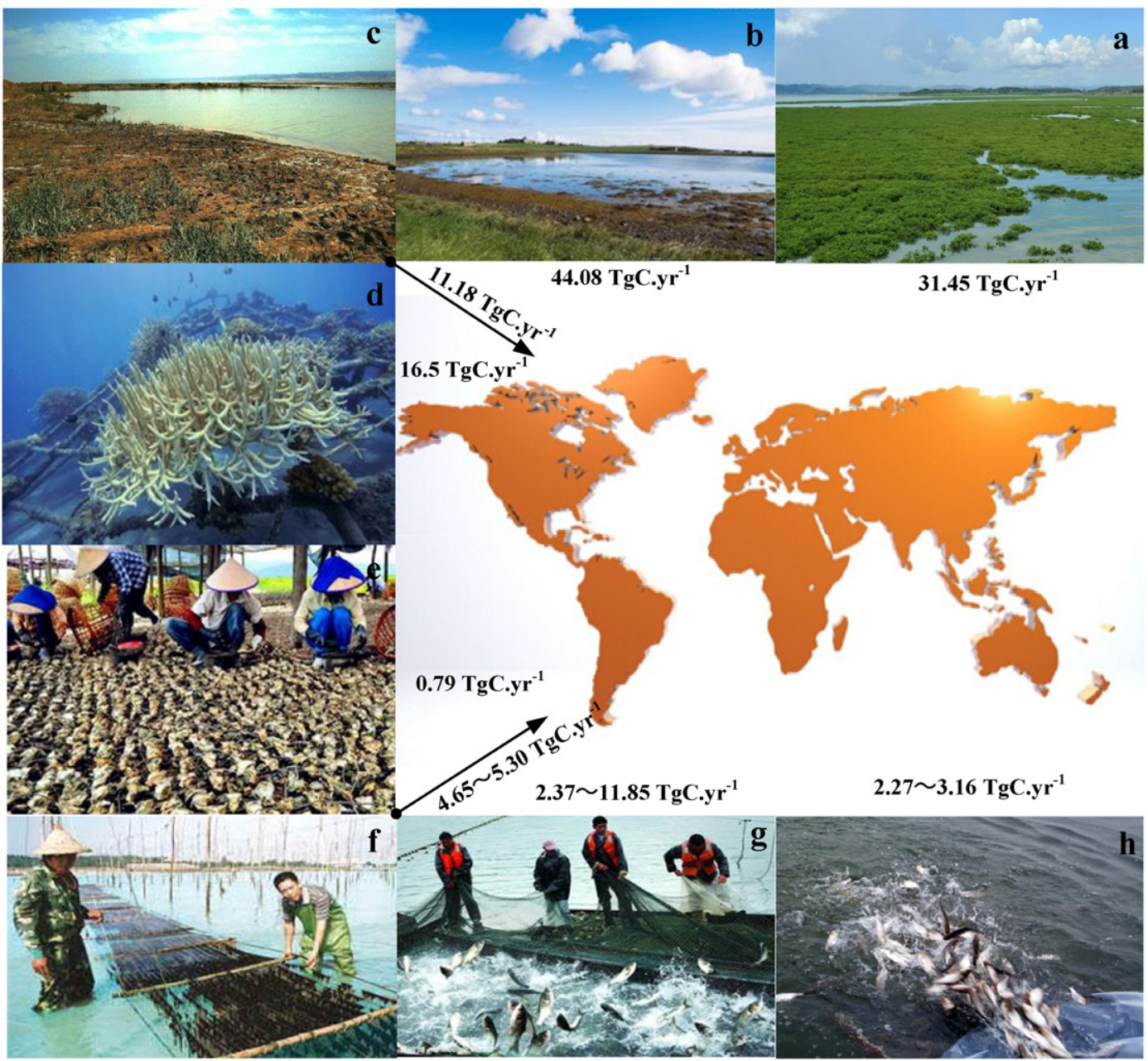

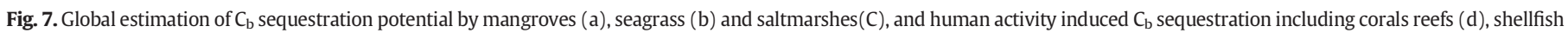
aquaculture (e), algae aquaculture (f), fish catching ( $g$ ) and fishery aquaculture $(\mathrm{h})$ in $\mathrm{C}_{\mathrm{b}}$ ecosystem.

\section{5. $C_{b}$ sink management and benefit}

\section{1. $C_{b}$ ecological service}

NEA (2011) defined ecosystem services as "the outputs of ecosystems from which people derive benefits". In present, the number of studies on $C_{b}$ sequestration and storage ecosystem service influenced by climate change is rapidly growing and this topic becomes a hotspot (Chung et al., 2011). $C_{b}$ ecosystems in coastal ecosystem only cover $0.5 \%$ of marine areas (da Silva Copertino, 2011), but it is associated with more than $55 \%$ of marine ecosystem services. Nellemann et al. (2009) estimated that $55 \%$ of $C$ would be removed by photosynthesis and stored by coastal ecosystems. The concept of reducing emissions from deforestation and forest degradation (REDD) are introduced to estimate the important ecosystem service on terrestrial C storage (da Silva Copertino, 2011; Luisetti et al., 2013). The use of REDD structure in estimating $C_{b}$ is a viable and promising mean leading to a better understanding of $C_{b}$ ecosystem services (Siikamäki et al., 2012).

Tang (2011) estimated that the amount of $C$ sequestration by algae and shellfish in China was equivalent to the annual contribution of $5 \times 10^{5} \mathrm{hm}^{2}$ afforestation area in absorbing atmospheric $\mathrm{CO}_{2}$ (Cao, 2011). Therefore, the estimated economic value of $C$ sequestration by algae and shellfish in the last ten years was about 500 billion RMB (approximately equal to 80.65 billion USD) afforestation expense (Tang, 2011). In present study, we estimate the $C_{b}$ ecosystem service by comparing with other ecosystems' $\mathrm{C}$ sequestration rates in China. As shown in Fig. 9, in China the $C$ sequestration potential in forest ecosystem is far higher than that in other ecosystem. According to Fang et al., 2007, the total C sequestration potential associated with forest was $75 \mathrm{TgC} \mathrm{yr}^{-1}$. Comparably, the $C$ sequestration potential in coastal $C_{b}$ ecosystem and $C_{b}$ sink fishery are approximately 1.47 and $7.1 \mathrm{TgC}^{-1}{ }^{-1}$, respectively. The total $C$ sequestration potential in $C_{\mathrm{b}}$ sink fishery is similar to that in grassland. The Chinese Karst area is considered as a new $C$ sink, in which the $C$ sequestration potential can reach

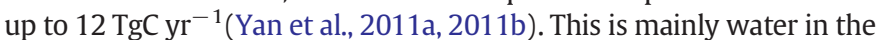
Karst area can potentially take up a significant amount of $\mathrm{CO}_{2}$ from the atmosphere due to the fact that the water in Karst area always contains large amount of calcium carbonate (Jiang and Yuan, 1999). Therefore, the $\mathrm{CO}_{2}$ deposition flux usually is much smaller than that of corrosion, enabling the Karst region to act as a net carbon sink (James et al., 2006; Yan et al., 2011a, 2011b). Based on our comparison, we think the coastal $C_{b}$ sink fishery and the Karst $C$ sink will become two of the most important causes for the $C$ sequestration potential increases in China in the future.

\section{2. $C_{b}$ sink estimation and management}

In coastal ecosystem research, understanding impacts of human activity on ecosystems that produce $C_{b}$ will aid in coastal $C$ cycle estimation accuracy. However, there is uncertainty on how to estimate global $C_{b}$ sequestration rates due to a lack of $C_{b}$ areal data from ecosystems as well as differences in $C$ burial rates between various ecosystems (Bouillon et al., 2008). Current studies have been focusing on investigating how deforestation affects global $\mathrm{C}$ cycles and how to effectively 


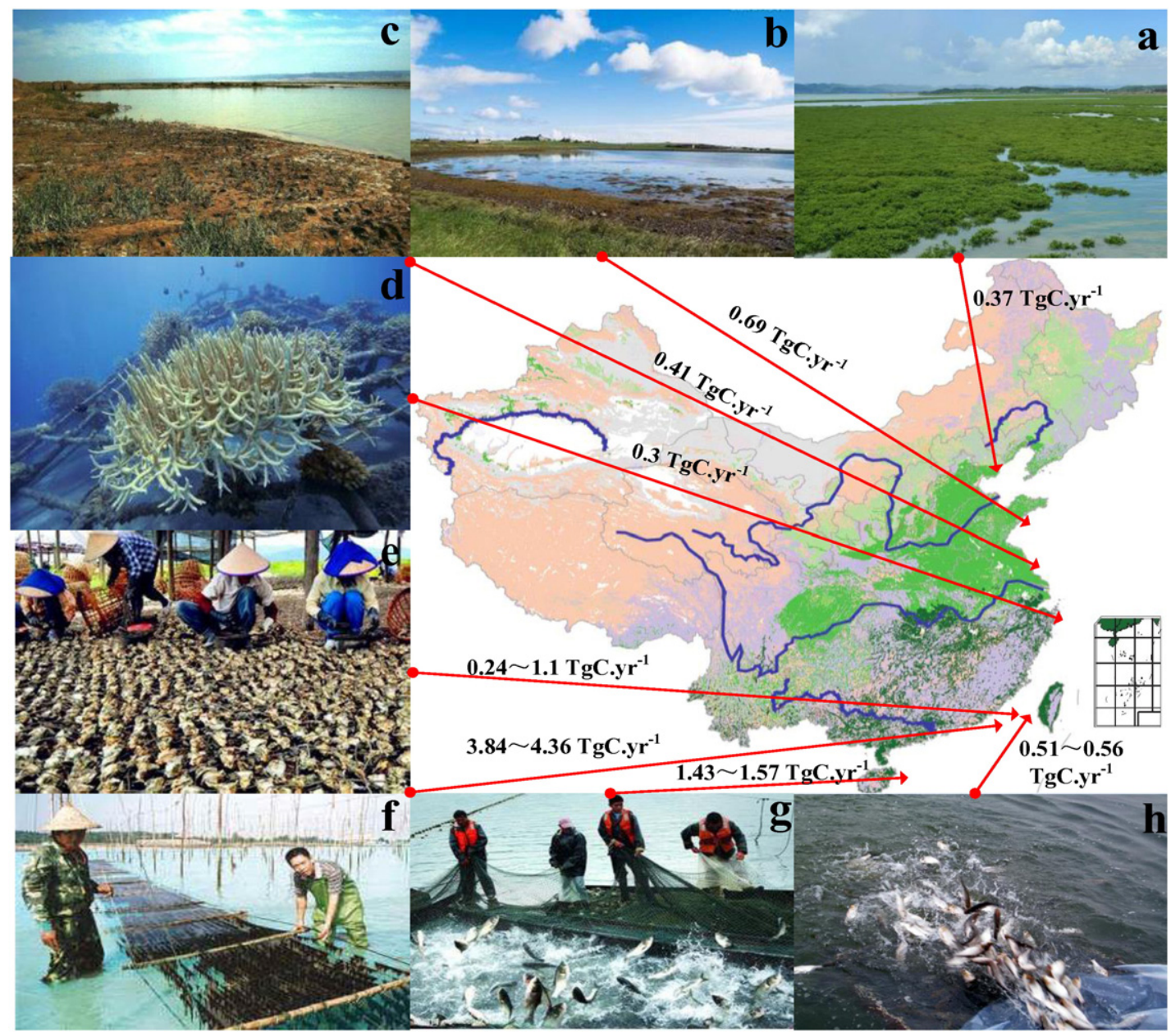

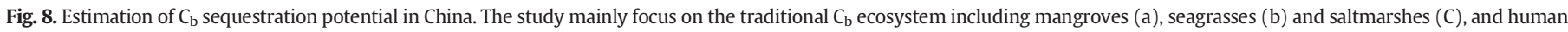
activity induced $C_{b}$ sequestration including corals reefs (d), shellfish aquaculture (e), algae aquaculture (f), fishing (g) and fishery culture (h) in coastal ecosystem.

regulate $\mathrm{CO}_{2}$ emissions. Nevertheless, it is still unclear whether $\mathrm{C}$ storage and sequestration in areas where land and sea interact can sufficiently absorb increases in prospective $\mathrm{CO}_{2}$ emissions. Future research should therefore focus on strengthening $C_{b}$ opportunity cost estimates as it pertains to ecosystem protection. Additionally, in some locations, such studies will also need to consider economic returns from aquaculture.

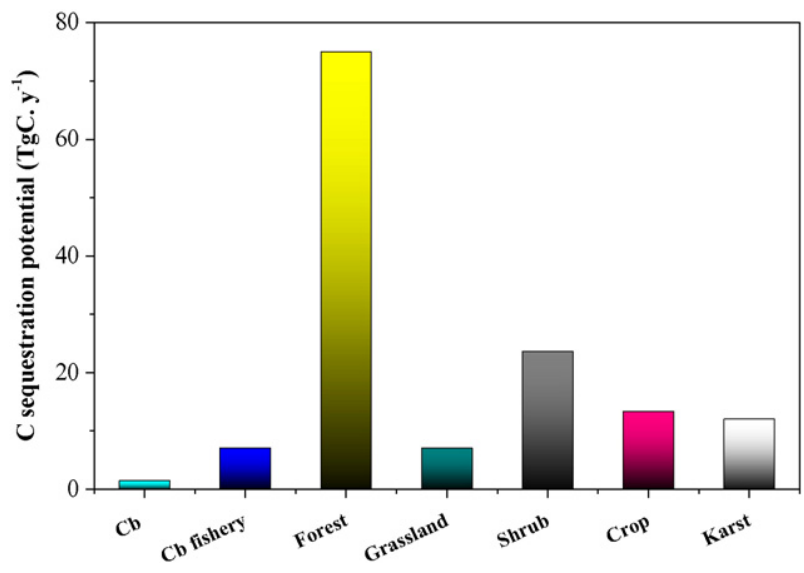

Fig. 9. $C$ sequestration rate in different main ecosystems in China for ecosystem service evaluation, wherein $C$ sequestration rate for different ecosystems are mainly from (Fang et al., 2007), except for Karst ecosystem from Yan et al.'s (2011a, 2011b) estimation.
Sustainable management strategies associated with $C_{b}$ sink activity are critical for coastal ecosystem protection and maintenance. The objective of such management strategies would be to quantify and subsequently control $C_{b}$ sequestration via algae as well as via shellfish aquaculture enterprises and coastal wetland areas themselves. As it pertains to coastal ecosystem management, it is important to differentiate between $C_{b}$ sequestration, storage types, functions, and areas impacted (Everard et al., 2010). Numerous governmental bodies have already acknowledged the important role that $\mathrm{C}_{\mathrm{b}}$ plays in ecosystems in mitigating climate change. On the other hand, it is important to accurately estimate and evaluate stored $C$ as well as investigate ecosystem mechanisms prior to implementing plans of action to successfully protect them from degradation. The United Nations Framework Convention on Climate Change (UNFCCC) has acknowledged that there are potential benefits in maintaining stored $C$ in ecosystems subject to $C_{b}$ propagation (Siikamäki et al., 2012).

\subsection{Implication for China}

Considering the great economic value of coastal ecosystems, China should focus on investigating how coastal $C_{b}$ propagation in ecosystem habitat conservation programs can be designed to promote the most economical and beneficial gains from fisheries and aquaculture that promote $C_{b}$ sinks. Future research should also focus more attention on evaluating the economic value of $C_{b}$ in ecosystems. For example, mangroves are considered to be suitable habitats for fisheries because they provide juvenile and adult fish populations with nursery habitats and food resources, respectively (Mumby et al., 2004; Mumby, 2006). 
Moreover, mangroves and coral reefs are believed to be interactively correlated to fish migration and reproduction (Twilley et al., 1996). Additionally, seagrass meadow habitats are always located near coral reefs and mangroves; therefore, this type of habitat is able to provide further connectivity to those areas as well as supporting fish species that rely on reefs and mangroves (Sanchirico and Springborn, 2011).

In the future, China must develop more fisheries that promote $C_{b}$ sinks based on seawater aquaculture as well as support "green" and low impact $C$ fishery enterprises. The Chinese government must also accelerate large-scale ocean-forest engineering development programs, such as establishing seagrass meadows and deepwater macroalgae aquaculture as well as advancing novel biomass energy material. Furthermore, it is critical to establish fishery measurement standards associated with $C_{b}$ sinks and, at the same time, build monitoring systems so that fisheries that promote $C_{b}$ sinks (as well as their associated development potential) can be systematically evaluated and explored. Finally, such a new biological monitoring and evaluating platform will help us to develop strategies to reduce $\mathrm{CO}_{2}$ emissions as well as potentially increase the number of $C$ sinks.

\section{Acknowledgements}

We thank Brian Doonan (McGill University, Canada) for his help in writing this paper and provide useful suggestions. This work is financially supported by the National Nature Science Foundation of China (Nos. 41571130043 and 31290223), the Chinese Academy of Sciences Strategic Priority Research Program (XDA05050702), State Key Laboratory of Urban and Regional Ecology Open Fund (SKLURE2015-2-2) and the Youth Innovation Promotion Association CAS. The authors also would like to thank the anonymous reviewers for their helpful remarks.

\section{References}

Allen, J.R.L., Pye, K., 1992. Saltmarshes: Morphodynamics, Conservation, and Engineering Significance. Cambridge University Press, Cambridge.

Arrigo, K.R., 2004. Marine microorganisms and global nutrient cycles. Nature 437 (7057), 349-355.

Atwood, T.B., Hammill, E., Richardson, J.S., 2014. Trophic-level dependent effects on $\mathrm{CO}_{2}$ emissions from experimental stream ecosystems. Glob. Chang. Biol. 20, 3386-3396

Atwood, T.B., Connolly, R.M., Ritchie, E.G., Lovelock, C.E., Heithaus, M.R., Hays, G.C., Fourqurean, J.W., Macreadie, P.I., 2015. Predators help protect carbon stocks in blue carbon ecosystems. Nat. Clim. Chang. 5, 1038-1045.

Baliño, B.M., Fasham, M.J.R., Bowles, M.C., 2001. Ocean biogeochemistry and global change. The International Geosphere-Biosphere Programme: A Study of Global Change of the International Council for Science (ICSU) Stockholm, Sweden.

Barbier, E.B., Hacker, S.D., Kennedy, C.J., Koch, E.W., Stier, A.C., Silliman, B.R., 2011. The value of estuarine and coastal ecosystem services. Ecol. Monogr. 81, 169-193.

Bauer, J.E., Cai, W.J., Raymond, P.A., Bianchi, T.S., Hopkinson, C.S., Regnier, P.A.G., 2013. The changing carbon cycle of the coastal ocean. Nature 504 (61), 61-69.

Bouillon, S., Borges, A.V., Castaneda-Moya, E. Diele, K., Dittmar, T. Duke, N.C., Kristensen, E., Lee, S.Y., Marchand, C., Middelburg, J.J., Rivera-Monroy, V.H., Smith, T.J., Twilley, R.R., 2008. Mangrove production and carbon sinks: a revision of global budget estimates. Glob. Biogeochem. Cycles 22 (2), GB2013.

Bowler, C., Karl, D.M., Colwell, R.R., 2009. Microbial oceanography in a sea of opportunity. Nature 459 (7244), 180-184

Cao, S.X., 2011. Impact of China's large-scale ecological restoration program on the environment and society: achievements, problems, synthesis, and applications. Crit. Rev. Environ. Sci. Technol. 41, 317-335.

Cebrian, J., 1999. Patterns in the fate of production in plant communities. Am. Nat. 154 (4), 449-468.

Charpy-Roubaud, C., Sournia, A., 1990. The comparative estimation of phytoplanktonic and microphytobenthic production in the oceans. Mar. Microb. Food. Webs. 4, 31-57.

Chen, C.T.A., Liu, K.K., Macdonald, R., 2003. The role of the ocean carbon cycle in globa change. In: Michael, J.R., Fasham (Eds.), Ocean Biogeochemistry, Chapter 3 Continental Margin Exchanges. Springer

China Fishery Statistical Yearbook (CFSY). 2012. Chinese Agricultural Press, Beijing

China Marine Statistical Yearbook (CMSY) 2000-2011. 2011.Ocean Press, Beijing.

Chmura, G.L., Anisfeld, S.C., Cahoon, D.R., Lynch, J.C., 2003. Global carbon sequestration in tidal, saline wetland soils. Glob. Biogeochem. Cycles 17 (4), 1111.

Chung, I.K., Beardall, J., Mehta, S., Sahoo, D., Stojkovic, S., 2011. Using marine macroalgae for carbon sequestration: a critical appraisal. J. Appl. Phycol. 23 (5), 877-886.

da Silva Copertino, M., 2011. Add coastal vegetation to the climate critical list. Nature 473 (7374), 255

Donato, D.C., Kauffman, J.B., Murdiyarso, D., Kurnianto, S., Stidham, M., Kanninen, M. 2011. Mangroves among the most carbon-rich forests in the tropics. Nat. Geosci. 4 (5), 293-297.
Duan, X.N., Wang, X.K., Lu, F., Ouyang, Z.Y., 2008. Carbon sequestration and its potential by wetland ecosystems in China. Ecol. Sin. 28 (2), 463-469.

Duarte, C.M., 2002. The future of seagrass meadows. Environ. Conserv. 29, 192-206.

Duarte, C.M., Cebrian, J., 1996. The fate of marine autotrophic production. Limnol. Oceanogr. 41 (8), 1758-1766.

Duarte, C.M., Chiscano, C.L., 1999. Seagrass biomass and production: a reassessment. Aquat. Bot. 65 (1-4), 159-174.

Duarte, C.M., Middelburg, J.J., Caraco, N., 2005. Major role of marine vegetation on the oceanic carbon cycle. Biogeosciences 2, 1-8.

Duarte, C.M., Holmer, M., Olsen, Y., Soto, D., Marbà, N., Guiu, J., Black, K., Karakassis, I., 2009. Will the oceans help feed humanity? Bioscience 59 (11), 967-976.

Duarte, C.M., Marbà, E., Gacia, J.W., Fourqurean, J., Beggins, C., Barrón, A.E.T., 2010. Seagrass community metabolism: assessing the carbon sink capacity of seagrass meadows. Glob. Biochem. Cycles 24, GB4032.

Duarte, C.M., Losada, I.J., Hendriks, I.E., Mazarrasa, I., Marbà, N., 2013. The role of coastal plant communities for climate change mitigation and adaptation. Nat. Clim. Chang. 3, 961-968

Everard, M., Jones, M.L.M., Watts, B., 2010. Have we neglected the societal importance of sand dunes? An ecosystem services perspective. Aquat. Conserv. Mar. Freshwat. Ecosyst. 20, 476-487.

Fang, J.Y., Guo, Z.D., Piao, S.L., Chen, A.P., 2007. Estimation of Chinese terrestrial ecosystem vegetation carbon sink from 1981 to 2000. Sci. Sin. Terrae 37 (6), 804-812 (In Chinese).

Food and Agriculture Organization (FAO), 2007. The world's Mangroves 1980-2005, Rome.

Food and Agriculture Organization of the United Nation (FAO), 20140. World Review of Fisheries and Aquaculture.

Frankignoulle, M., Canon, C., 1994. Marine calcification an source of carbon dioxide: positive feedback of increasing atmospheric $\mathrm{CO}_{2}$. Limnol. Oceanogr. 39, 456-462.

Gattuso, J.P., Frankignoulle, M., Wollast, R., 1998. Carbon and carbonate metabolism in coastal aquatic ecosystems. Annu. Rev. Ecol. Syst. 29, 405-434.

Ghebrehiwet, B., Tantral, L., Titmus, M.A., Panessa-Warren, B.J., Tortora, G.T., Wong, S.S., Warren, J.B., 2009. The exosporium of $B$. cereus contains a binding site for gc1qr/p33: implication in spore attachment and/or entry. Adv. Exp. Med. Biol. 598, 181-187.

Giri, C., Zhu, Z., Tieszen, L.L., Singh, A., Gillette, S., Kelmelis, J.A., 2007. Mangrove forest distributions and dynamics (1975-2005) of the tsunami-affected region of Asia. J. Biogeogr. 35, 519-528.

Giri, C.E., Ochieng, E., Tieszen, L.L., Zhu, Z., Singh, A., Loveland, T., Masek, J., Duke, N., 2011. Status and distribution of mangrove forests of the world using earth observation satellite data. Glob. Ecol. Biogeogr. 20, 154-159.

Gonzalez, P., Neilson, R.P., Lenihan, J.M., Drapek, R.J., 2010. Global patterns in the vulnerability of ecosystems to vegetation shifts due to climate change. Glob. Ecol. Biogeogr. 19 (6), 755-768.

Green, E.P., Short, F.T., Gebrehiwet, T., Koretsky, C.M., Krishnamurthy, R.V., 2003. World Atlas of Seagrasses. California University Press, BerkeleyInfluence of spartina and juncus on saltmarsh sediments. III. Organic geochemistryChem. Geol. 255, pp. 114-119.

Guy, H., 2010. The microbial role in carbon cycling within seagrass sediments. Plymouth Stud. Sci. 3 (1), 234-244.

Heck, K.L., Carruthers, T.J.B., Duarte, C.M., Hughes, A.R., Kendrick, G., Orth, R.J., Williams, S.W., 2008. Trophic transfers from seagrass meadows subsidize diverse marine and terrestrial consumers. Ecosystems 11 (7), 1198-1210.

Hemminga, M.A., Duarte, C.M., 2000. Seagrass Ecology. Cambridge University Press, Cambridge.

IWGCBC (International Working Group on Coastal "Blue" Carbon), 2011o. Minimizing Carbon Emissions and Maximizing Carbon Sequestration and Storage by Seagrasses, Tidal Marshes, Mangroves: Recommendations from the International Working Group on Coastal "Blue" Carbon.

James, U.LB., Lisa, M.B., Frank, M., Nicholas, C., 2006. Carbon dioxide source, sinks, and spatial variability in shallow temperate zone cave: evidence from Ballynamintra Cave, Ireland. J. Cave Karst Stud. 68 (1), 4-11.

Jiang, Z., Yuan, D., 1999. $\mathrm{CO}_{2}$ source-sink in karst processes in karst areas of China. Episodes $22(1), 33-35$

Kaiser, M., Attrill, M., Jennings, S., Thomas, D.N., Barnes, D., Brierley, A., Polunin, N., Raffaelli, D., Williams, P.L.B., 2005. Marine Ecology: Processes, Systems, and Impacts. Oxford University Press, Oxford.

Kennedy, H., Beggins, J., Duarte, C.M., Fourqurean, J.W., Holmer, M., Marba, N., Middelburg, J.J., 2010. Seagrass sediments as a global carbon sink: isotopic constraints. Glob. Biogeochem. Cycles 24, GB4026

Kong, D.X., Miao, C.Y., Borthwick, A.G.L., Duan, Q.Y., Liu, H., Sun, Q.H., Ye, A.Z., Di, Z.H. Gong, W., 2015. Evolution of the Yellow River Delta and its relationship with runoff and sediment load from 1983 to 2011. J. Hydrol. 520, 157-167.

Kristensen, E., Denmark, O.M., Bouillon, S., Dittmar, T., Marchand, C., 2008. Organic carbon dynamics in mangrove ecosystems: a review. Aquat. Bot. 89 (2), 201-219.

Laffoley, D., Grimsditch, G. (Eds.), 2009. The Management of Natural Coastal Carbon Sinks. IUCN, Gland, Switzerland.

Lan, Z.H., Chen, G.Z., 2006. Destruction and conservation countermeasures of coral reef in South China Sea. Ecol. Environ. 15 (2), 430-434 (In Chinese).

Lavery, T.J., Roudnew, B., Seymour, J., Seuront, L., Johnson, G., Smetacek, V., 2010. Iron defecation by sperm whales stimulates carbon export in the Southern Ocean. Proc. Roy Soc B. 277, 3527-3531.

Leonard, L., Luther, M., 1995. Flow hydrodynamics in tidal marsh canopies. Limnol. Oceanogr. 40, 1474-1484.

Luisetti, T., Jackson, E.L., Turner, R.K., 2013. Valuing the European 'coastal blue carbon' storage benefit. Mar. Pollut. Bull. 71, 101-106.

Macreadie, P.I., Baird, M.E., Trevathan-Tackett, S.M., Larkum, A.W.D., Ralph, P.J., 2014. Quantifying and modelling the carbon sequestration capacity of seagrass meadows: a critical assessment. Mar. Pollut. Bull. 83, 430-439. 
Mateo, M.A., Romero, J.M., Perez, M., Littler, M., 1997. Dynamics of millenary organic deposits resulting from the growth of the Mediterranean seagrass Posidonia oceanica. Estuar. Coast. Shelf Sci. 44, 103-110.

Miao, C.Y., Ni, J.R., Borthwick, A.G.L., Yang, L., 2011. A preliminary estimate of human and natural contributions to the changes in water discharge and sediment load in the Yellow River. Glob. Planet. Chang. 76 (3-4), 196-205.

Miao, C.Y., Ashouri, H., Hsu, K., Sorooshian, S., Duan, Q.Y., 2015. Evaluation of the PERSIANN-CDR daily rainfall estimates in capturing the behavior of extreme precipitation events over China. J. Hydrometeorol. 16, 1387-1396.

Middelburg, J.J., Duarte, C.M., Gattuso, J.P., 2005. Respiration in coastal benthic communities. In: del Giorgio, P.A., Williams, P.J.lB. (Eds.), Respiration in Aquatic Ecosystems. Oxford Univ. Press, Oxford, U. K., pp. 206-224.

Mitsch, W.J., Gosselink, J.G., Cebrian, J., 1993. Wetlands, second ed. John, W.S., New YorkPatterns in the fate of production in plant communitiesAm. Nat. 154 (4), pp. 449-468.

Mumby, P.J., 2006. Connectivity of reef fish between mangroves and coral reefs: algorithms for the design of marine reserves at seascape scales. Biol. Conserv. 128, 215-222.

Mumby, P.J., Edwards, A.J., Arias-Gonzalez, J.E., Lindeman, K.C., Blackwell, P.G., Gall, A.G., Malgosia, I., Harbome, A.R., Pescod, C.L., Renken, H.W., Colette, C.C., Llewellyn, G., 2004. Mangroves enhance the biomass of coral reef fish communities in the Caribbean. Nature 427, 533-536.

NEA, 2011. UK National Ecosystem Assessment. 2011. The UK National Ecosystem Assessment: Synthesis of the Key Findings. UNEP-WCMC, Cambridge.

Nellemann, C., Corcoran, E., Duarte, C.M., Valdés, L., De Young, C., Fonseca, L., Grimsditch, G., 2009. Blue carbon. A Rapid Response Assessment Vol. 80. United Nations Environment Programme, GRID-Arendal).

Pendleton, L., Donato, D.C., Murray, B.C., Crooks, S., Jenkins, W.A., Sifleet, S., Craft, C., Fourqurean, J.W., Kauffman, J.B., Marba, N., Megoniagal, P., Pidgeon, E., Herr, D. Gordon, D., Baldera, A., 2012. Estimating global "blue carbon" emissions from conversion and degradation of vegetated coastal ecosystems. PLoS One 7 (9), e43542.

Regnier, P., Friedlingstein, P., Ciais, P., Mackenzie, F.T., Gruber, N., Janssens, I.A., Laruelle, G.G., Lauerwald, R., Luyssaert, S., Andersson, A.J., Arndt, S., Arnosti, C., Borges, A.V. Dale, A.W., et al., 2013. Anthropogenic perturbation of the carbon fluxes from land to ocean. Nat. Geosci. 6, 597-607.

Sanchirico, J., Springborn, M., 2011. How to get there from here: ecological and economic dynamics of ecosystem service provision. Environ. Resour. Econ. 48, 243-267.

Sifleet, S.D., Pendleton, L., Murray, B.C., 2011. State of the Science on Coastal Blue Carbon: A Summary for Policy Makers. Duke Nicholas Institute for Environmental Policy Solutions.

Siikamäki, J., Sanchirico, J.N., Jardine, S., McLaughlin, D., Morris, D.F., 2012. Blue Carbon: Global Options for Reducing Emissions from the Degradation and Development of Coastal Ecosystems. Resources for the Future.

Song, J.M., 2011. Carbon cycling processes and carbon fixed by organisms in China marginal seas. J. Fish. Sci. China 18 (3), 703-711 (In Chinese).
Spalding, M.D., Kainuma, M., Collins, L., 2010. World Atlas of Mangroves. Earthscan, London, p. 319

Suratman, M.N., 2008. Carbon sequestration potential of mangroves in Southeast Asia. In: Bravo, F., Jandl, R., LeMay, V., Gadow, K. (Eds.), Managing Forest Ecosystems: The Challenge of Climate Change. Springer, The Netherlands, pp. 297-315.

Tang, Q.S., 2011. Carbon fishery and rapidly development of modern fishery- carbon fishery and low carbon fishery technology. Jiangxi J. Fish. Sci. 2, 4-8 (In Chinses).

Theuerkauf, E.J., Stephens, J.D., Ridge, J.T., Fodrie, F.J., Rodriguez, A.B., 2015. Carbon export from fringing saltmarsh shoreline erosion overwhelms carbon storage across a critical width threshold. Estuar. Coast. Shelf Sci. 164, 367-378.

Twilley, R.R., Chen, R.H., Hargis, T., 1992. Carbon sinks in mangroves and their implications to carbon budget of tropical coastal ecosystems. Water Air Soil Pollut. 64 (1) 265-288.

Twilley, R.R., Medina, E., Snedaker, S.C., Yañez-Arancibia, A., 1996. Biodiversity and ecosystem processes in tropical estuaries: perspectives of mangrove ecosystems. In: Mooney, H.A., Cushman, J.H., Medina, E., Sala, O.E., Schulze, E.D. (Eds.), Functional Roles of Biodiversity: A Global Perspective. John Wiley \& Sons, Chichester, UK pp. 327-370.

Wilmers, C.C., Estes, J.A., Edwards, M., Laidre, K.L., Konar, B., 2012. Do trophic cascades affect the storage and flux of atmospheric carbon? An analysis of sea otters and kelp forests. Front. Ecol. Environ. 10, 409-415.

Wilson, R.W., Millero, F.J., Taylor, J.R., Wa1sh, P.J., Christensen, V., Jennings, S., Grosell, M., 2009. Contribution of fish to the marine inorganic carbon cycle. Science 323, 359.

Yan, L., Huang, H.J., Chen, J.T., Yang, X.G., 2011a. Estimation of carbon sink capacity in the coastal areas of of algal mariculture China. Adv. Mar. Sci. 29 (4), 537-543 (In Chinese).

Yan, J., Wang, Y.P., Zhou, G., Li, S., Yu, G., Li, K., 2011b. Carbon uptake by karsts in the Houzhai Basin, southwest China. J. Geophys. Res. 116, G04012.

Yang, J., Su, Y.P., Liu, H.B., Ge, X.P., 2012. Characteristics of carbon cycles and mechanism of carbon sink in inland fishery ecosystem. J. Fish. China 36 (5), 794-800 (In Chinese).

Yang, T., Gao, X., Sellars, S.L., Sorooshian, S., 2015. Improving the multi-objective evolutionary optimization algorithm for hydropower reservoir operations in the California Oroville-Thermalito complex. Environ Modell Softw 69, 262-279.

Zhang, X.J., 2013. A Research of Carbon Sink Based on the Technology of XRF Measuring Carbon for Marine Culture of Shellfish in China. Liaoning Normal University (Master dissertation). (In Chinese).

Zhang, J.H., Fang, J.G., Tang, Q.S., 2005. The contribution of shellfish and seaweed mariculture in China to the carbon cycle of coastal ecosystem. Adv. Earth Sci. 20 (3), 359-365 (In Chinese).

Zhang, H.B., Luo, Y.M., Liu, X.H., Fu, C.C., 2015. Current researches and prospects on the coastal blue carbon. Sci. Sin. Terrae 45, 1641-1648 (in Chinese).

Zheng, F.Y., Qiu, G.L., Fan, H.Q., Zhang, W., 2013. Diversity, distribution and conservation of Chinese seagrass species. Biodivers. Sci. 21 (5), 517-526 (In Chinese). 